\title{
Assessment of ecological efficiency of the scheme of agrolandscape formation at the level: system of gullen drainage areas $\rightarrow$ gullen drainage area of the Aidar River
}

\author{
Belolipskyi V. ${ }^{1}$, Poluliakh M. ${ }^{2}$ \\ National Research Center «Institute of soil science and agrochemistry named after \\ O.N. Sokolovsky» \\ 4 Chaikovska Str., Kharkiv, 61024, Ukraine \\ e-mail: ${ }^{1}$ belolipskiy-42@ukr.net, ${ }^{2}$ nick_pol2015@ukr.net \\ ORCID: ${ }^{1} 0000-0003-2177-8615,{ }^{2} 0000-0002-7947-4158$
}

Goal. To assess ecological efficiency of the scheme of formation of agrolandscapes at the level: system of gullen drainage areas $\rightarrow$ gullen drainage areas of the Aidar river. Methods. Laboratory-field, mathematical-statistical, topometric, morphological. Results. The basic erosionecological situation of the object of research is determined. PS levels are calculated for the Steppe zone. An Integral map of soil erosion hazard classes of the Steppes of Ukraine is constructed. At the level of the system of gullen drainage areas of the Aidar River, the analysis is carried out of the nature of the impact of forecast and actual erosion-hydrological indicators (runoff costs) on the development of erosion-hydrological processes on a probabilistic basis $(1 ; 5 ; 10 ; 50 \%)$ by their ratio. On the example of the Yevsuh and Kovsuh river basins, plowing indicators are calculated for key drainage areas along the river with differentiation of administrative land use. The map of the structure of the Yevsug and Kovsug river basins within the drainage areas is constructed. The structure of sown areas and their plowing is assessed according to the potential runoff indicator: up to $5 \mathrm{~mm}$ - insignificant, $5.1-8$ - weak, $8.1-15 \mathrm{~mm}$ - moderate, with erosion index levels ( 3 and lower; $3-4 ; 4-5 ; 5$ and above) and grouping the structure of sown areas. According to the simplex method, the analysis of actual and forecast erosion-hydrological indicators and optimization of the structure of sown areas is carried out. For the Aidar River basin the model structure of crop rotations is obtained. Ecological assessment of the structure of crop rotations is performed according to the coefficient of ecological danger of crop rotations. Conclusions. At the level of the gullen drainage areas system, the coefficient of the ratio of KV of forecast and actual losses of the river runoff as an indicator of the development of erosionhydrological processes on a probabilistic basis $(1 ; 5 ; 10 ; 50 \%)$ at hydro-posts along the Aidar River showed that at $10 \%$ security in case of reduction of plowed lands to $50-60 \%$, a high level of runoff reduction $(81-90 \%)$ was observed at the Bakhmutivka hydro-post, medium $(73-85 \%)$ — at Bilolutsk and Starobilsk hydro-posts, the lowest — at the Kuriachivka hydro-post ( $39-65 \%)$. The study of humus content in the range of $4.5-5.5 \%$ by groups of arable land areas $40-60 \%$ revealed constant decrease in Qmax (average maximum runoff losses) in the range of $8-9 \%$. At the level of individual gullen drainage areas, the determination of the basic erosion-ecological situation of the object of research on the integrated map of erosion hazard classes of steppe soils of Ukraine showed its belonging to the class of moderate erosion hazard with runoff of 8.1-15.0 $\mathrm{mm}$.

Key words: basin, drainage areas, hydro-post, slopes, humus, runoff, costs, factors, coefficient.

DOI: https://doi.org/10.31073/agrovisnyk202010-09

The main goal of creating a unified system for managing water resources in the basin is to optimize water use and increase the number of used water resources in the basin by applying a unified basin approach that combines territorial and administrative interests. The essence of the ecosystem-basin approach to water resources management is to shift the focus from the water bodies themselves to the entire basin and to systems of girder catchments and individual girder reservoirs in agricultural landscapes in order to fully cover all possible causes of environmental violations, intersectoral and inter-territorial contradictions and to prevent and eliminate negative phenomena [1-7].

Basins are the most objective natural basis for solving many problems in the field of rational natural science $[8,9]$. The effectiveness and duration of the system of catchment channels depends on their compliance with the landscape and environmental conditions of the territory [10-12]. 
In Ukraine, at the regional level and within the entire territory of basin structures, practically targeted development of small and medium-sized rivers is not carried out. The water strategy for minimizing erosion processes in agricultural landscapes is based on research conducted in the Aidar river basin $[13,14]$, it was used for soil and water management of agricultural landscapes at a new information level $[15,16]$.

Objects and methods of research. The goal is to assess the environmental efficiency of the agro-landscape formation scheme at the level of: system of girder catchments $\rightarrow$ girder reservoirs R. Aidar. Object - soil and water protection arrangement of agricultural landscapes on a basin basis. Subject - ecological efficiency of the scheme of formation of agroland-shaftiv at the level of: system of beam catchments $\rightarrow$ beam reservoirs of Aidar. The place of geographical research beyond the question is the Aidar river basin on the territory of Troitskiy, Novopskovskiy, Bilokurakinskiy, Markivskiy, Starobilskiy and Novoaydarskiy districts of Luhansk region; additions, testing, development and analysis of experimental material were performed for the catchments of the Evsug and Kovsug rivers on the territory of Novoaydarskiy, Starobilskiy, Belovodskiy, StanychnoLuhansk districts.

Research problem. 1) Determination of ecological efficiency of application of schemes of formation of agricultural landscapes on catchments.

2) Develop anti-erosion measures taking into account the erosion indices of land safety in the system of girder catchments, confined to the Aidar river hydro stations.

3) Develop anti-erosion measures at the level of beam catchments based on the analysis of the ratio of the structure of acreage and potential runoff.

Research methods. To achieve the research goal in the context of the tasks set, the following methodological approaches are used.

1. Indicators of storm costs in modern economic activities are characterized by maximum rainfall floods of small rivers and quantified models medium maximum discharges of the river flow $\left(Q_{\text {мах }}\right)$ with different probability of exceedance $(10,25,50 \%)$ - the term "cost of river runoff" is used in the system: the small river's basin-system water-beamed - beamed catchment [13].

Management of the maximum flow of rain floods of the river (with the exception of the flow rate of the river) is carried out by geoinformation modeling of erosion processes on the basis of erosion indices of land safety in the system of girder catchments, confined to the hydroposts of the small river basin [13].

2. To determine the nature of the interaction of forecast (acceptable) and actual parameters for the development of erosion and hydrological processes in order to minimize them on a probabilistic basis $(10,25,50 \%)$ with the corresponding parameters of flow rates, the coefficient of their ratio Ctr is calculated (formula 1).

$$
C_{t r}=\frac{Q_{10 \ldots 50 \text { forecast }}}{Q_{10 \ldots 50 \text { fact }}}
$$

3. Geoinformation modeling of erosion processes in the Evsug and Kovsug river basins, taking into account the structure of acreage on a basin basis.

To model erosion processes as an indicator of the intensity of erosion-hydrological processes (situations), the erosion index of land Availability (Ei) of various Availability levels is used: as a ratio of $Q_{\max } 10 \ldots 50 \%$ probability of exceeding the flow rate to the average value of the statistical series of observations $Q_{\max } 50 \%$ probability by formu

$$
E_{i}=\frac{Q_{10 \ldots . \ldots 0}}{Q_{50 \%}}
$$

where $Q_{1-50 \%}$ - average maximum flow costs $1-50 \%$ probability, $Q_{50 \%}$ - average maximum flow costs $50 \%$ probability, $\mathrm{m}^{3} / \mathrm{s}$ [13].

4. Ecological efficiency of application of the scheme of formation of agro-landscapes on beam catchments.

The problem is solved using the linear programming method (simplex method), in which the target function and main variables are selected, as well as a system of constraints that should give a fairly complete subject-specific characteristic of erosion and hydrological processes. The ecological efficiency of the scheme of forming the agrolandscape at 2 levels (system of girder catchments $\rightarrow$ girder reservoirs) is considered.

At the first level, the optimality criterion is the coefficient of the ratio of actual and acceptable indicators of average-maximum flow rates $\left(\mathrm{C}_{\mathrm{tr}}\right)$.

At the second level, the optimality criterion is the requirement to increase the potential runoff to an environmentally acceptable level $-5 \mathrm{~mm}$ (PR $\rightarrow E A L)$ [10] with the model structure of acreage. 
Results and discussion. At the system level of beam catchments to complete the ecological assessment of the ecological efficiency of the scheme for the formation of agricultural landscapes, an analysis of the nature of interaction between forecast and actual erosion and hydrological indicators (flow costs in small rivers) for the development of erosion and hydrological processes based on probability theory was carried out $(1,5,10,50 \%)$ by calculating the coefficient of their ratio $\mathrm{C}_{\text {tr }}$ according to the formula 1 according to the average-maximum flow rates of the corresponding probability, $\mathrm{m} 3 / \mathrm{s}$ [13].

Models of average-maximum flow costs of $10,25,50 \%$ of Availability are calculated based on the system dependence (formula 3 ):

$$
\begin{aligned}
& Q_{10,25,50 \%}=A_{10,25,50 \%} \cdot F^{0,2485} \cdot X^{1,7422} \cdot f_{n}^{5,3333} \cdot \mathrm{S}_{\mathrm{sl}}^{0,5194} \cdot \mathrm{F}_{\text {hum }}{ }^{-0,402} \\
& \cdot \mathrm{S}_{\mathrm{gbn}} \mathrm{-}^{-0,087} \cdot \mathrm{S}_{\mathrm{ft}}^{-0,009} \cdot \mathrm{S}_{\mathrm{tbb}}^{-0,022} \cdot \mathrm{S}_{\mathrm{pl}} \mathrm{Pl}^{-0,008}
\end{aligned}
$$

where $\quad A_{10,25,50 \%}$ is the coefficient for probabilities: $A_{10 \%}=8,79 \cdot 10^{-13}, A_{25 \%}=1,14 \cdot 10^{-14}$,

$A_{50 \%}=4,0 \cdot 10_{-18} ;$

$\mathrm{F}$ - percentage of the catchment area within the key area;

$X$ - storm precipitation, $\mathrm{mm} ; \mathrm{f}_{\mathrm{n}}$ - devastation, \%; $\mathrm{S}_{\mathrm{sl}}-$ slopes $>1, \%$;

$\mathrm{F}_{\text {hum }}$ - humus content, \%; $\mathrm{S}_{\mathrm{gbn}}$ - gully-beam network, \%;

$\mathrm{S}_{\mathrm{tt}}$ - the first terrace of the river, \%; $\mathrm{S}_{\mathrm{ttb}}$ - transverse forest belts, \%

$\mathrm{S}_{\mathrm{pl}}$ - plateau (slopes up to $1^{0}$ ), $\%$.

Model adequacy indicators: multiple correlation coefficient:

$R=0,904$, relative error of model $E=2,17 \%$.

The value of the $C_{t r}$ coefficient characterizes the degree of decrease in the flow rate values in the case of reduced ploughing of catchment lands (table 1).

1. The ratio $Q_{\text {forecast }} / Q_{\text {fact }}$ of different provision of hydroposts in the catchment area of the river Aidar

\begin{tabular}{|l|c|c|c|c|c|}
\hline \multirow{2}{*}{ Hydroposts } & \multirow{2}{*}{ The plowed, $\%$} & \multicolumn{4}{|c|}{ Availability, \% } \\
\cline { 2 - 6 } & & $\mathrm{Q}_{1}$ & $\mathrm{Q}_{5}$ & $\mathrm{Q}_{10}$ & $\mathrm{Q}_{50}$ \\
\hline \multirow{3}{*}{ Bilolutsk } & 40 & 0,09 & 0,08 & 0,07 & 0,02 \\
\cline { 2 - 6 } & 50 & 0,19 & 0,16 & 0,15 & 0,07 \\
\hline \multirow{3}{*}{ Kuryachivka } & 60 & 0,31 & 0,29 & 0,27 & 0,16 \\
\cline { 2 - 6 } & 40 & 0,20 & 0,18 & 0,17 & 0,08 \\
& 50 & 0,38 & 0,36 & 0,35 & 0,22 \\
\hline \multirow{3}{*}{ Starobilsk } & 60 & 0,62 & 0,60 & 0,61 & 0,49 \\
& 40 & 0,09 & 0,08 & 0,07 & 0,02 \\
\hline \multirow{3}{*}{ Bahmutivka } & 50 & 0,19 & 0,17 & 0,15 & 0,07 \\
& 60 & 0,32 & 0,29 & 0,27 & 0,16 \\
\cline { 2 - 6 } & 40 & 0,07 & 0,05 & 0,04 & 0,01 \\
\cline { 2 - 6 } & 50 & 0,14 & 0,12 & 0,10 & 0,04 \\
\cline { 2 - 6 } & 60 & 0,23 & 0,21 & 0,19 & 0,10 \\
\hline
\end{tabular}

With $10 \%$ availability of flow expenditure in the case of a decrease in the water catchment land area to the level of $50-60 \%$, the highest level of flow reduction (81-90\%) was observed at the Bakhmutivka hydropost, the average (73-85\%) at the Bilolutsk and Starobilsk hydroposts, and the lowest - at the Kuryachivka hydropost (39-65\%).

There is a steady trend to strengthen soil protection by reducing plowing for all road posts and ensuring flow costs, which is clearly expressed in a decrease in the ratio of forecast and actual indicators of flow costs, and especially the level of $50 \%$ Availability is highlighted.

According to the hydro stations along the Aidar river (Bilolutsk $\rightarrow$ Starobilsk $\rightarrow$ Bakhmutivka) in the upper and middle parts, almost the same ratio of forecast and actual indicators of flow costs and its change in the lower part (Bakhmutivka) was found. Separately, this relatively high ratio is allocated to the Kuryachivka hidropost catchment, since it is a self-independent catchment of the Belaya river with a coefficient of ravines $\mathrm{Kr}=0.95 \mathrm{~km} / \mathrm{km}^{2}$ (in comparison: Bilolutsk 0,75 , Starobilsk - 0,81, Bakhmutivka $-0,88 \mathrm{~km} / \mathrm{km}^{2}$ ).

Studies of humus content in the range of $4.5-5.5 \%$ for groups of arable land areas of $40-$ $60 \%$ revealed a constant decrease in Qmax in the range of 8-9\%. Therefore, the detailed minimization of the erosion-hydrological process should be considered when developing a set of antierosion measures in the agricultural block of the agro-landscape for groups of eroded soils.

In the block of ecological interrelations of acceptable indicators of combinations of components of the agrolandscape, the areas of transverse forest belts $(0,3-0,5 \%)$ contribute to a slight decrease in $\mathrm{Q}_{\max }$ by dependence $\left(\mathrm{S}_{\mathrm{tbb}}{ }^{-0,022}\right)$ - formula 3. 
At the level of individual beam catchments the analysis of the ratio of the structure of acreage and potential runoff is performed in accordance with the following methodological principles:

Assessment of the erosion-hydrological and ecological situation in the agricultural landscapes of the beam catchments.

In solving this issue, it is necessary to proceed from the need to determine the main erosion and environmental conditions of the studied objects. This allows to form both scientifically substantiated general schemes of soil and water protection measures, and to create functional models of agrolandscape as a foundation for elementary design.

As one of the options, the calculation of PR runoff can be performed using the formula [10], converted for generalized studies in the form:

$Q_{\Pi C}=1,352 \cdot 10^{-5} \cdot R^{4.33} \cdot X_{\alpha} \cdot X_{A} \cdot K_{G C} \cdot K_{A E M}$,

where $\mathrm{R}-$ is the erosion index of rain of $10 \%$ availability;

$X_{\alpha}$ - weighted average slope steepness by region;

$X_{A}$ - weighted average coefficient of the flow-regulating role of the agrofone of the corresponding structure of sown areas by districts;

$K_{G C}-$ flow-regulating role of ground cover;

$K_{A E M}-$ flow-regulating role of reclamation (anti-erosion) measures.

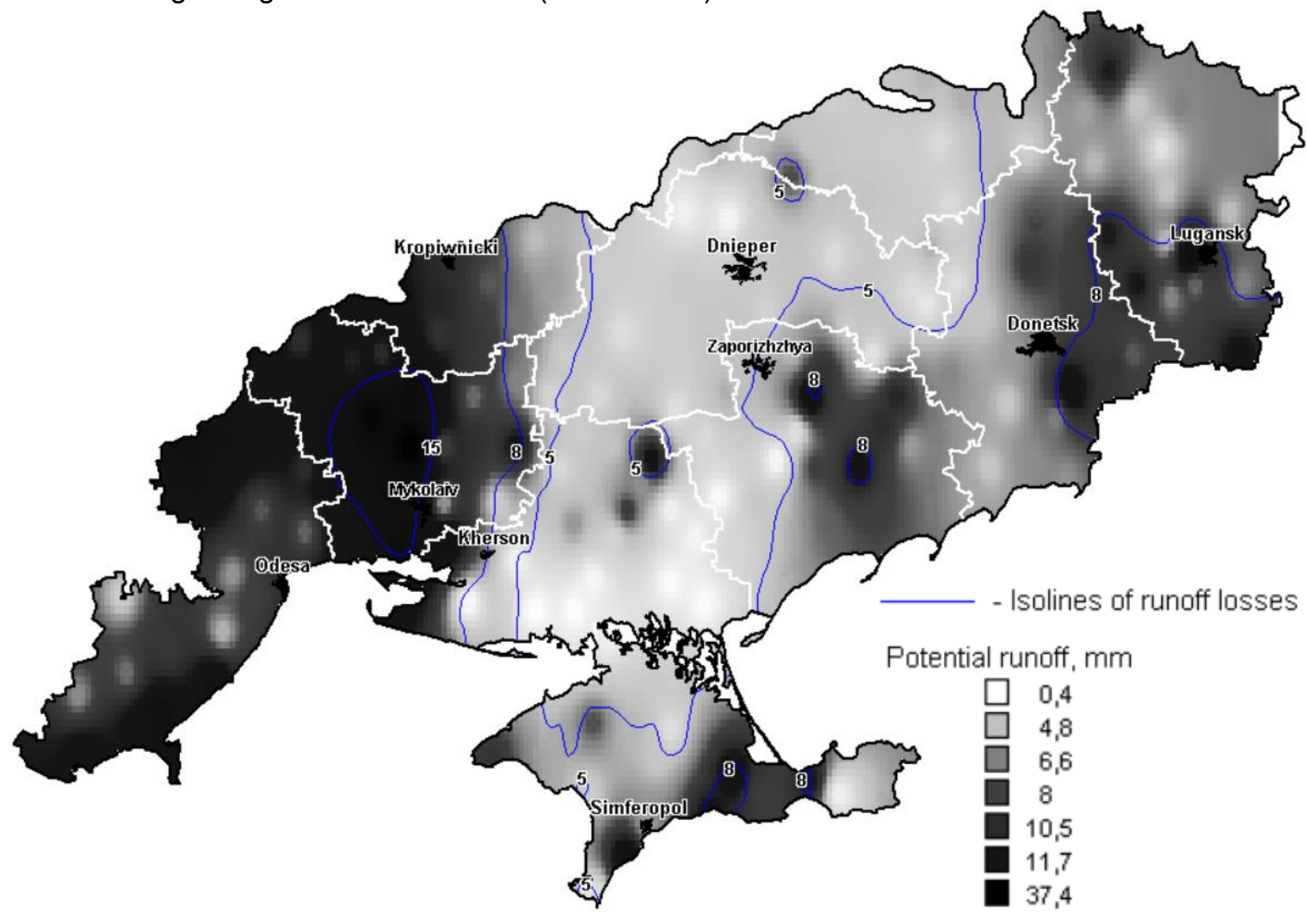

Fig. 1. Integrated map of soil classes for erosion hazard of the Steppe of Ukraine

The value of the PR is determined for each administrative district and, in accordance with the classification, zoning is carried out by regions of the Ukrainian Steppe territory, followed by drawing up an integral map of classes according to the degree of manifestation of potential runoff (Fig. 1). the map Scheme is the starting point for determining the directions of reliable protection of soil cover.

Probabilistic quantitative assessment of PR allows us to determine the degree of potential danger in modern agroecosystems under certain natural conditions, and is the basis for forecasting and designing soil protection measures.

The object of our research is located in the South-East of Ukraine and is characterized by a PR indicator within the range of $8-15 \mathrm{~mm}$.

The legend of the integrated map looks like this (table 2). 
2. Indicators and their normalization for the integrated map of erosion and hydrological zoning of the Steppe of Ukraine [10]

\begin{tabular}{|c|c|c|c|c|c|}
\hline \multirow{2}{*}{$\begin{array}{l}\text { Factors of ero- } \\
\text { sion and hydro- } \\
\text { logical zoning }\end{array}$} & \multicolumn{5}{|c|}{ Soil classes for erosion hazard (Runoff Q mm) } \\
\hline & $\begin{array}{l}\text { I- insignifi- } \\
\text { cant, up to } \\
5\end{array}$ & $\begin{array}{l}\text { II - weak, } \\
5,1-8,0\end{array}$ & $\begin{array}{l}\text { III - moder- } \\
\text { ate, } 8,1-15,0\end{array}$ & $\begin{array}{l}\text { IV - large, } \\
15,1-25,0\end{array}$ & $\begin{array}{c}\mathrm{V}-\text { very } \\
\text { large, }>25.0\end{array}$ \\
\hline $\begin{array}{l}\text { Erosive rain in- } \\
\text { dex } 10 \% \text { Avail- } \\
\text { ability }(R)\end{array}$ & 17,5 & 21,0 & 22,5 & 23,5 & $>25$ \\
\hline $\begin{array}{l}\text { Flow-regulating } \\
\text { role of soil } \\
\text { cover }\left(K_{G C}\right)\end{array}$ & $\begin{array}{l}\text { 0,81-0,95 } \\
\text { typical } \\
\text { cherno- } \\
\text { zems }\end{array}$ & $\begin{array}{c}1 \\
\text { ordinary } \\
\text { cherno- } \\
\text { zems }\end{array}$ & $\begin{array}{c}1,2-1,4 \\
\text { chernozems } \\
\text { are dark gray }\end{array}$ & $\begin{array}{c}1,45-1,5 \\
\text { chernozems } \\
\text { gray }\end{array}$ & $\begin{array}{c}1,6-2,2 \\
\text { chernozems } \\
\text { turf }\end{array}$ \\
\hline $\begin{array}{l}\text { Coefficient of } \\
\text { the agricultural } \\
\text { Fund's flow- } \\
\text { regulating role } \\
\left(X_{A}\right)\end{array}$ & $\begin{array}{c}0,29 \\
\text { perennial } \\
\text { grass }\end{array}$ & $\begin{array}{l}0,38 \\
\text { winter } \\
\text { wheat }\end{array}$ & $\begin{array}{c}0,43 \\
\text { spring spike- } \\
\text { lets }\end{array}$ & $\begin{array}{l}0,45 \\
\text { corn }\end{array}$ & $\begin{array}{c}1 \\
\text { steam with } \\
\text { stubble }\end{array}$ \\
\hline $\begin{array}{l}\text { Weighted aver- } \\
\text { age slope } \\
\text { steepness by } \\
\text { district }(X \boldsymbol{\alpha})\end{array}$ & $1^{\circ}$ & $1,3^{\circ}$ & $3,1-5^{\circ}$ & $5,1-7^{\circ}$ & $>7^{\circ}$ \\
\hline $\begin{array}{l}\text { Flow-regulating } \\
\text { role of anti-ero- } \\
\text { sion techniques }\end{array}$ & $\begin{array}{c}0,11-0,25 \\
\text { flat-cut pro- } \\
\text { cessing } \\
\text { with slitting }\end{array}$ & $\begin{array}{l}0,26-0,35 \\
\text { flat-cut fin- } \\
\text { ish with } \\
\text { mole seal- } \\
\text { ing }\end{array}$ & $\begin{array}{l}0,36-0,50 \\
\text { fallow plow- } \\
\text { ing }\end{array}$ & $\begin{array}{c}1 \\
\text { flat-cut plow- } \\
\text { ing across } \\
\text { the slope }\end{array}$ & $\begin{array}{l}1,45-1,49 \\
\text { flat-cut plow- } \\
\text { ing along the } \\
\text { slope }\end{array}$ \\
\hline
\end{tabular}

On a basin basis, anti-erosion measures in agricultural landscapes should be implemented dynamically and differentially, taking into account the erosion and hydrological situation. Strategy program implementation protarsi development of agricultural landscapes is based on the change in cropping patterns (that is, the changes in the project scope of land use and increase storehouse the role of soil fertility) and includes the following steps:

Stage 1. Calculations of weighted average ploughing indicators on a basin basis with analysis of the structure of the river basin. The example of the Evsug and Kovsug river basins shows the differentiation of administrative land use corresponding to key catchment areas along the river (Fig. 2, table 3). the Methodological approach used to determine the ploughing of the territory does not contradict the basin principle, because it considers the issue of determining the weighted average ploughing in the structure of the Entire Evsug and Kovsug river basins with the differentiation of administrative land use in the catchment areas of rivers. 


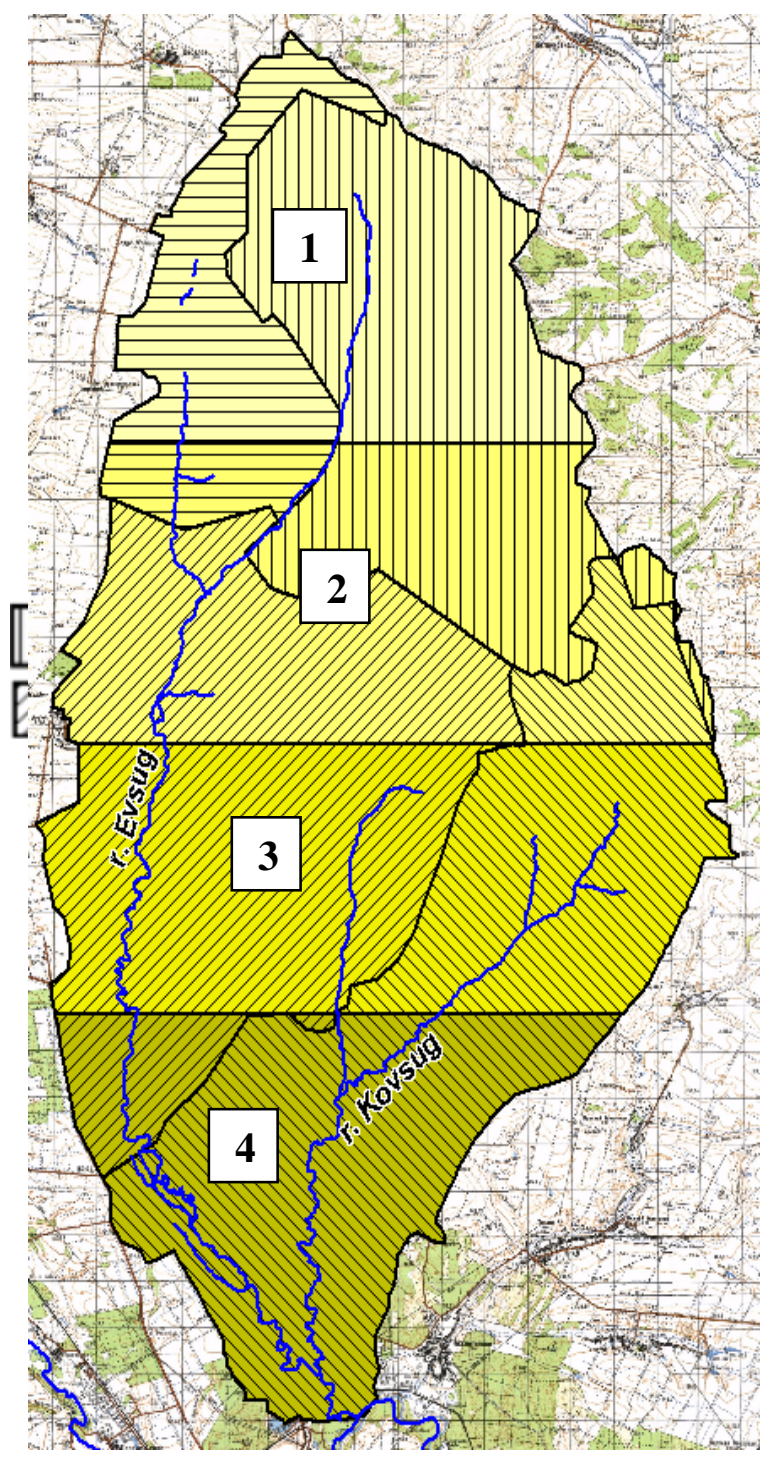

$$
\begin{aligned}
& \text { Administrative districts: } \\
& \text { - Belovodskiy - Starobilskiy } \\
& \text { - Novoaydarskiy _ - Stanychno- } \\
& \text { - Rivers } \\
& \text { Luhanskiy } \\
& \text { Catchment areas: } \\
& \text { - upper } \\
& \text { - average } \\
& \text { - lower } \\
& \text { - estuary }
\end{aligned}
$$

Fig. 2. The structure of the basin of the river Evsug and Kosug within catchment areas

3. Estimated ploughing of areas corresponding to key catchment areas

\begin{tabular}{|l|c|c|c|c|c|}
\hline \multirow{2}{*}{ Administrative district } & \multirow{2}{*}{$\begin{array}{c}\text { Thrown open af- } \\
\text { ter districts \% }\end{array}$} & \multicolumn{4}{|l|}{ Area of arable earths in key areas - catchment areas, } \\
\cline { 3 - 5 } & & 1 & 2 & 3 & 4 \\
\cline { 3 - 6 } & & 257,5 & 344,5 & 344,5 & 254,5 \\
\hline Starobilskiy & 75,0 & 90,2 & 30,9 & & \\
\hline Bilovodskiy & 69,37 & 166,3 & 116,6 & & \\
\hline Novoaydarskiy & 68,89 & & 153 & 198,9 & 34,7 \\
\hline Stanychno-Luhanskiy & 71,68 & & 42 & 142,6 & 215,8 \\
\hline \multicolumn{2}{|c|}{ Plowing is weighted average } & 71,07 & 69,54 & 69,44 & 70,17 \\
\hline
\end{tabular}

Thus, the integrated (weighted average) ploughing area corresponding to the key catchment areas is $69,44-71,17 \%$.

Stage 2. Accounting for changes in the structure of acreage and ploughing. For the period of the last years of land use (2014-2018), the soil and water-saving capacity of agricultural landscapes was estimated, which is numerically expressed by the indicator of potential runoff: up to $5 \mathrm{~mm}$ - insignificant, 5,1-8 -weak, 8,1-15 mm - moderate $10 \%$ availability [10].

Stage 3. Assessment of the impact of the structure of acreage on potential runoff by the levels of the erosion index (up to $3,3-4,4-5,5$ ) and grouping of the structure of acreage table 4 . 
4. Structure of acreage for erosion index levels in the Aidar river catchment area

\begin{tabular}{|c|c|c|c|c|c|c|c|c|}
\hline \multirow{2}{*}{$\begin{array}{c}\text { Erosion } \\
\text { index lev- } \\
\text { els }\end{array}$} & \multirow{2}{*}{\begin{tabular}{c} 
Area, ha \\
\cline { 3 - 9 }
\end{tabular}} & \multicolumn{6}{|c|}{ The structure of sown areas, \% } \\
\cline { 3 - 9 } & steam & $\begin{array}{c}\text { winter } \\
\text { wheat }\end{array}$ & corn & $\begin{array}{c}\text { spring } \\
\text { cereals }\end{array}$ & sunflower & $\begin{array}{c}\text { perennial } \\
\text { grasses }\end{array}$ & $\begin{array}{c}\text { other cul- } \\
\text { tures }\end{array}$ \\
\hline$<3$ & 93040 & 11,89 & 15,26 & 11,05 & 7,77 & 39,63 & 1,57 & 12,83 \\
\hline $3-4$ & 107112 & 13,33 & 15,04 & 11,01 & 7,08 & 36,36 & 1,84 & 15,34 \\
\hline $4-5$ & 198284 & 14,15 & 17,49 & 10,36 & 6,51 & 36,11 & 1,30 & 14,07 \\
\hline$>5$ & 103440 & 14,47 & 17,43 & 9,27 & 5,83 & 35,98 & 1,17 & 15,85 \\
\hline
\end{tabular}

The structure of sown areas is dominated by two economically profitable crops - winter wheat $(15,04-17,49 \%)$ and sunflower $(35,98-39,64 \%)$. Areas under corn $-9,27-11,05 \%$, under spring cereals decreased to $5,38-7,77 \%$, under steam $-11,89-14,47 \%$. The area of erosion resistant soil fertility (perennial grasses) - low (of 1.17 to $1.84 \%$ ).

Stage 4. Improving the erosion and hydrological situation by:

- application of anti-erosion measures in the form of changes in the method of basic tillage, and in the calculation of runoff coefficients of anti - erosion measures in the agrofone, for which the following values should be used: black steam (treatment KPG) - 0,53; winter (surface cultivation of BDT) - 0,98; corn (main non - fallow cultivation) - 0,98; spring cereals (shallow non - fallow cultivation) - 0,53; sunflower (treatment KPG) - 0,53; perennial grasses- 0,12 , other crops (shallow soil-free cultivation) $-0,53$.

- transfer of arable land to slopes up to $3^{\circ}$ and adjustment of the ratio of arable land, forage land, forest belts. Control of erosion processes is performed using the factor $X_{\alpha}$, and through it the spatial restriction of the action of $K_{G C}$ (soil cover and its eroding) is carried out.

- internal organization of the field, that is, the allocation of working areas in parallel-contour and fixing them with the boundaries of permanent action: new construction of forest belts, hydraulic structures (shafts-ditches, shafts-terraces). In addition, the technological block for growing agricultural crops is supplemented with special soil protection measures, and feedlands are used efficiently.

- modeling the structure of acreage for administrative areas of the basin (steam -12-14, winter crops $-32-33$, corn $-13-17$, sunflower $-16-17$, perennial grasses $-3-4$, other crops $-2,5-$ $6,0 \%)$.

Stage 5. Solving the problem using linear programming. As a criterion of optimality in the linear programming problem $[17,18,19]$, the requirements of $P R \rightarrow E A L$ (environmentally acceptable level $-5 \mathrm{~mm}$ ) were adopted (see table. 2) $[10,16]$ with the actual structure of sown areas (steam, winter, corn, spring cereals, sunflower, perennial grasses and other crops,\%) and given restrictions-runoff coefficients (Css - slope steepness, $\mathrm{C}_{\mathrm{A}}$-agrophone, $\mathrm{C}_{\mathrm{aem}}$ - anti-erosion measures), $\mathrm{R}$ - erosion index of precipitation:

- $\quad$ structure of acreage: $\%$ steam $+\%$ winter $+\%$ corn $+\%$ spring $+\%$ sunflower $+\%$ grass $+\%$ other $=100 \%$;

- $C_{s s}-$ slope steepness: $C_{s s 1}+C_{s s 2}+C_{s s 3}+C_{s s 4}+C_{s s 5}+C_{s s 6}+C_{s s 7}=16,8$

- $C_{A}$ - agricultural background: $C_{A 1}+C_{A 2}+C_{A 3}+C_{A 4}+C_{A 5}+C_{A 6}+C_{A 7}=0,496$;

- $\mathrm{C}_{\mathrm{aem}}-$ anti-erosion measures: $\mathrm{C}_{\mathrm{aem} 1}+\mathrm{C}_{\mathrm{aem} 2}+\mathrm{C}_{\mathrm{aem} 3}+\mathrm{C}_{\mathrm{aem} 4}+\mathrm{C}_{\mathrm{aem} 5}+\mathrm{C}_{\mathrm{aem} 6}+\mathrm{C}_{\mathrm{aem} 7}=$ 0,734 ;

- $R_{-}$- erosion index of precipitation: $R_{1}+R_{2}+R_{3}+R_{4}+R_{5}+R_{6}+$ $R_{7}=140,7$.

Below are the formulas $(5,6,7)$ for calculating runoff coefficients (agrophone, anti-erosion measures) and potential runoff [10], as well as initial data for analyzing the structure of acreage beyond the catchment area Aidar river (table 5 ).

$$
\begin{aligned}
& \mathrm{C}_{\mathrm{A}}=\left(1 \cdot \%_{\text {steam }}+0,38 \cdot \%_{\text {winter crops }}+0,46 \cdot \%_{\text {corn }}+0,43 \cdot \%_{\text {spring }}+0,5 \cdot \%_{\text {sunflower }}+0,29 \cdot \%_{\text {grass }}\right. \\
& +0,43 \cdot \% \text { other) } / 100 \% \\
& \mathrm{C}_{\text {aem }}=(0,53 \cdot \%+0,98 \cdot \% \text {, } \\
& \left.\%_{\text {grass }}+0,53 \cdot \% \text { other }\right) / 100 \% \\
& P R=1,352 \cdot 10^{-5} \cdot R \cdot \mathrm{Css}_{\mathrm{ss}} \cdot \mathrm{C}_{\mathrm{A}} \cdot \mathrm{C}_{\mathrm{aem}} \\
& +0,53 \cdot \%_{\text {spring }}+0,53 \cdot \%_{\text {sunflower }}+0,12
\end{aligned}
$$


5. Output data of cluster analysis of the structure of sown areas behind the level of the erosion index in the territory of the Aidar river basin

\begin{tabular}{|c|c|c|c|c|c|c|c|c|c|c|c|c|}
\hline \multirow[b]{2}{*}{ 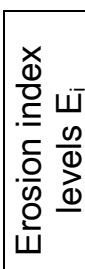 } & \multicolumn{7}{|c|}{ The structure of sown areas, \% } & \multicolumn{4}{|c|}{$\begin{array}{l}\text { The coefficients of regula- } \\
\text { tion of runof }\end{array}$} & \multirow[b]{2}{*}{$\begin{array}{l}\text { PR, } \\
\text { MM }\end{array}$} \\
\hline & $\begin{array}{l}\frac{E}{D} \\
\frac{\Phi}{\omega}\end{array}$ & 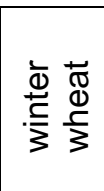 & 气 & 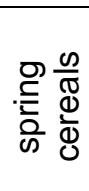 & $\begin{array}{l}\frac{\bar{d}}{3} \\
\frac{0}{\omega} \\
\frac{0}{5} \\
\omega\end{array}$ & 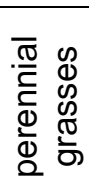 & 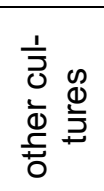 & 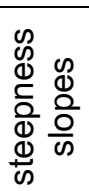 & $\begin{array}{l}\text { 음 } \\
\text { 임 } \\
\text { त }\end{array}$ & 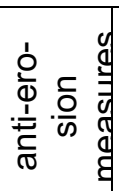 & $\simeq$ & \\
\hline$<3$ & 11,89 & 15,26 & 11,05 & 7,77 & 39,63 & 1,57 & 12,83 & 2,36 & 0,52 & 0,98 & 21,1 & 9,3 \\
\hline 3-4 & 13,33 & 15,04 & 11,01 & 7,08 & 36,36 & 1,84 & 15,34 & 2,44 & 0,52 & 0,98 & 21,2 & 10,1 \\
\hline $4-5$ & 14,15 & 17,49 & 10,36 & 6,51 & 36,11 & 1,30 & 14,07 & 2,35 & 0,53 & 0,98 & 19,0 & 6,0 \\
\hline$>5$ & 14,47 & 17,43 & 9,27 & 5,83 & 35,98 & 1,17 & 15,85 & 2,50 & 0,53 & 0,98 & 20,0 & 8,0 \\
\hline
\end{tabular}

Stage 6. Identification of ways to achieve the goal of the target function $(P R \rightarrow E A L$ $<5 \mathrm{~mm}$ ) was carried out by modeling the structure of sown areas by groups of forecast erosion and hydrological indicators $(>8,5,1-8,<5 \mathrm{~mm}$ ) for water intake in Aidar (table 6).

6. Forecast erosion and hydrological indicators for water intake in Aidar with the existing structure of acreage (2014-2018)

\begin{tabular}{|c|c|c|c|c|c|c|c|}
\hline \multicolumn{7}{|c|}{ The structure of sown areas, \% } & \multirow{2}{*}{$\begin{array}{c}\text { PR, } \\
\text { MM }\end{array}$} \\
\cline { 1 - 6 } steam & $\begin{array}{c}\text { winter } \\
\text { wheat }\end{array}$ & corn & $\begin{array}{c}\text { spring ce- } \\
\text { reals }\end{array}$ & sunflower & $\begin{array}{c}\text { perennial } \\
\text { grasses }\end{array}$ & $\begin{array}{c}\text { other cul- } \\
\text { tures }\end{array}$ & \\
\hline \multicolumn{7}{|c|}{ Erosion index levels $\mathrm{E}_{\mathrm{i}}<3$} \\
\hline $8,2-15,2$ & $14,1-15,4$ & $10,6-11,3$ & $6,5-11,3$ & $32,8-40,5$ & $0,3-8,2$ & $11,9-15,0$ & $>8$ \\
\hline $5,7-7,9$ & $8,5-13,8$ & $6,9-10,5$ & $11,7-15,2$ & $12,7-31,5$ & $9,3-37,8$ & $14,3-16,3$ & $5,1-8,0$ \\
\hline $4,0-6,8$ & $6,5-8,2$ & $5,3-6,7$ & $10,7-13,8$ & $9,2-12,1$ & $39,8-52,7$ & $10,7-13,9$ & $<5,0$ \\
\hline \multicolumn{7}{|c|}{ Erosion index levels $\mathrm{E}_{\mathrm{i}} 3-4$} \\
\hline $7,6-16,6$ & $13,0-15,4$ & $10,1-11,5$ & $6,0-13,0$ & $26,3-37,1$ & $0,1-12,7$ & $14,6-17,4$ & $>8$ \\
\hline $5,4-7,5$ & $8,0-12,8$ & $6,6-10,0$ & $13,2-15,6$ & $11,6-25,7$ & $13,4-41,4$ & $13,6-17,4$ & $5,1-8,0$ \\
\hline $4,5-6,6$ & $7,1-7,7$ & $5,8-6,3$ & $12,1-13,0$ & $9,4-11,1$ & $43,7-48,9$ & $11,6-13,0$ & $<5,0$ \\
\hline \multicolumn{7}{|c|}{ Erosion index levels $\mathrm{E}_{\mathrm{i}} 4-5$} \\
\hline $7,9-17,4$ & $15,1-17,7$ & $9,9-11,0$ & $5,5-11,4$ & $29,3-3,5$ & $0,1-9,3$ & $13,4-16,4$ & $5,1-8,0$ \\
\hline $4,6-8,0$ & $7,4-14,6$ & $6,1-10,3$ & $12,1-15,5$ & $10,6-27,8$ & $10,9-46,1$ & $12,5-17,0$ & $<5,0$ \\
\hline \multicolumn{7}{|c|}{ Erosion index levels $\mathrm{E}_{\mathrm{i}}>5$} \\
\hline $14,9-17,4$ & $17,3-17,5$ & $8,8-9,2$ & $4,9-5,6$ & $36,1-36,2$ & $0,1-0,9$ & $15,3-15,8$ & $>8$ \\
\hline $6,3-13,3$ & $10,0-17,6$ & $8,0-10,2$ & $6,1-15,1$ & $16,0-36,1$ & $1,4-28,3$ & $16,1-17,7$ & $5,1-8,0$ \\
\hline $5,73-6,14$ & $8,6-9,5$ & $7,0-7,7$ & $14,3-15,0$ & $12,8-14,8$ & $31,0-37,0$ & $14,6-15,9$ & $<5,0$ \\
\hline
\end{tabular}

It was found that achieving the target function (PR $<5 \mathrm{~mm}$ ) for the levels of the erosion index (from 3 to $>5$ ) is possible by forming the structure of crops with limiting sunflower crops to $(12-15 \%)$, increasing perennial grasses to $(37-50 \%)$.

Stage 7. The ecological assessment of the crop rotation structure was performed based on the coefficient of ecological hazard of crop rotations $\left(\mathrm{C}_{\text {encr }}\right)$, calculated as the ratio of the sum of areas of erosion-hazardous agrofone (steam, corn, sunflower) to areas of erosion-resistant (winter, spring cereals, perennial grasses, and others).

$$
K_{\text {ehcr }}=\frac{S_{\text {steam }}+S_{\text {corn }}+S_{\text {sunflower }}}{S_{\text {winter what }}+S_{\text {springcereals }}+S_{\text {perennialgrasses }}+S_{\text {other }}}
$$

Figure 3 shows the dependence of potential runoff on the ecological hazard coefficient of crop rotations. It is characterized by the formula:

$$
Y=3,1389 e^{0,647 x}
$$

Coefficient correlation point $R=0,9923$ with this structure of crop rotations: steam 0,34 19,0 , winter crops $-28,64-30,4$, corn $-11,68-12,99$, spring cereals $-15,27-18,88$, sunflower $16,48-19,59$, perennial grasses $-6,3-13,0$ and other crops $-2,57-6,28 \%$. 


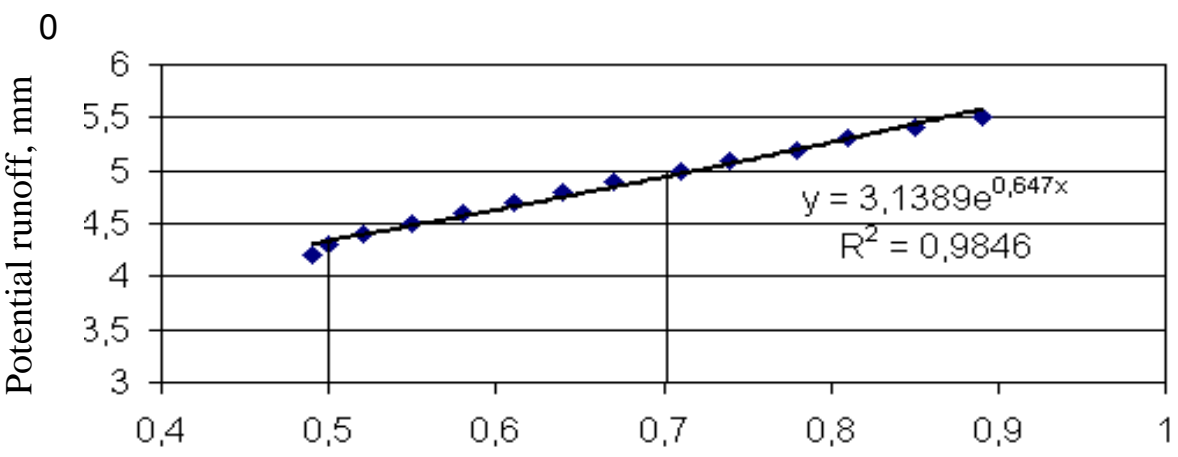

Fig. 3. Dependence of potential runoff on the coefficient environmental hazards of crop rotations

The environmentally acceptable level (EAL) of potential runoff - up to $5 \mathrm{~mm}$ corresponds to the coefficient of erosion hazard of crop rotations $\mathrm{C}_{\text {ehcr }}$ 0,49-0,67.

Thus, we have identified rational ways to create a system of soil-water-protection measures in agricultural landscapes at the level of: the system of girder catchments $\rightarrow$ girder reservoirs in Aidar. The degree of risk of water-erosion processes and the environmental circumstances determine different levels of reliability renovationa events (table. 7).

Summarized complex anti-erosion measures in the basin based sent, respectively:

1. System-level beam watersheds - on the differentiation of plowing on a probabilistic basis of the expenditure flow.

2. At the level of individual beam catchments - to identify the need to optimize the structure of sown areas and the use of anti-erosion agricultural measures.

\section{Set of anti-erosion measures on a basin basis [16]}

\begin{tabular}{|c|c|c|c|c|c|}
\hline № & $\begin{array}{c}\text { Natural and anthro- } \\
\text { pogenic } \\
\text { basin level }\end{array}$ & \multicolumn{4}{|c|}{$\begin{array}{l}\text { Management measures that correspond to the erosion and hy- } \\
\text { drological situation }\end{array}$} \\
\hline \multirow[t]{6}{*}{1} & $\begin{array}{l}\text { The system of } \\
\text { beam watersheds }\end{array}$ & \multicolumn{4}{|c|}{$\begin{array}{c}\text { Differentiation of arable land depending on } \mathrm{Q}_{\max } \\
\text { by probability, \%: }\end{array}$} \\
\hline & \multirow{5}{*}{$\begin{array}{l}\text { with hydroposts: } \\
\text { - Bilolutsk } \\
\text { - Kuryachivka } \\
\text { - Starobilsk } \\
\text { - Bahmutivka }\end{array}$} & $\mathrm{Q}_{1}$ & $Q_{5}$ & $Q_{10}$ & $Q_{50}$ \\
\hline & & 40 & 50 & 50 & 60 \\
\hline & & 40 & 40 & 40 & 50 \\
\hline & & 40 & 50 & 50 & 60 \\
\hline & & 40 & 50 & 50 & 60 \\
\hline \multirow[t]{5}{*}{2} & Beam catchments & \multicolumn{4}{|c|}{$\begin{array}{l}\text { The need to differentiate the structure of acreage by levels of } \\
\text { erosion index }(+,-) \text { : }\end{array}$} \\
\hline & \multirow{4}{*}{$\begin{array}{l}\text { - Bilolutsk } \\
\text { - Kuryachivka } \\
\text { - Starobilsk } \\
\text { - Bahmutivka }\end{array}$} & $<3$ & $3-4$ & $4-5$ & $>5$ \\
\hline & & + & + & + & - \\
\hline & & + & + & + & - \\
\hline & & - & $\begin{array}{l}+ \\
-\end{array}$ & $\begin{array}{l}+ \\
+\end{array}$ & $\begin{array}{l}+ \\
-\end{array}$ \\
\hline
\end{tabular}

\section{Conclusions}

At the level of the beam catchment system, the ratio coefficient $C_{r}$ of forecast and actual river flow losses as an indicator of the development of erosion and hydrological processes on a probabilistic basis $(1,5,10,50 \%)$ for hydroposts along the Aidar river, showed that with $10 \%$ Availability in the case of reducing the ploughed land catchments to the level of 50-60\%, a high level of reduction in runoff (81-90\%) is observed at the Bahmutivka hydropost, the average (7385\%) at the Bilolutsk and Starobilsk hydroposts, and the smallest - at the Kuryachivka hydropost (39-65\%). Studies of humus content in the range of 4,5-5,5\% for groups of arable land areas of 40-60\% revealed a constant decrease in $Q_{\max }$ (mid-maximum flow losses) in the range of 8-9\%. Therefore, the detailed minimization of the erosion-hydrological process should be considered when developing a set of anti-erosion measures in the agricultural block of the agro-landscape for groups of eroded soils.

At the level of individual beam catchments, the determination of the basic erosion-ecological situation of the object of research using the integrated map of erosion hazard classes of soils of the Steppe of Ukraine showed that it belongs to the class of moderate erosion hazard with a flow of 8,1-15,0 $\mathrm{mm}$. 
GIS technologies allow conducting administrative and territorial analysis in order to obtain indicators of ploughing according to the basin principle. The integrated (weighted average) ploughing area corresponding to the key catchment areas is $69,44-71,17 \%$.

It is advisable to optimize the structure of acreage using the simplex method for potential runoff of an environmentally acceptable level $(5 \mathrm{~mm})$ and the coefficient of erosion hazard of crop rotations $C_{\text {ehcr }}$ 0,49-0,67 with the structure of crop rotations: fallow - up to 10,7\%, winter - 29,1330,4 , corn - 12,29-12,99, spring cereals - 16,88-18,88, sunflower - 17,9-19,59, perennial crops $-9.22-13,1$ and other crops $-4,18-6,18 \%$.

\section{References}

1. Korytnyy, L.M. (2001). Basseynovaya kontseptsiya v prirodopolzovanii [Basin concept in nature management]. Irkutsk: Institute Publishing House. [in Russian].

2. Shvebs, G.I., \& Lisetskiy, F.N. (1989). Proektirovanie konturno-meliorativnoy sistemy pochvozashchitnogo zemledeliya [Design

1. contour-reclamation system of soil shield agriculture]. Agriculture, 2,55-59. [in Russian].

2. Trifonova, T.A. (2005). Razvitie basseynovogo podkhoda v pochvennykh i ekologicheskikh issledovaniyakh [Basin development approach in soil and ecological research gifts]. Soil science, 9, 32 - 39. [in Russian].

3. Narozhnyaya A.G., \& Kuzmenko Ya.V. (2012). Basseynovoe prirodopolzovanie pri okhrane okruzhayushchey sredy [Basin use of natural resources while protecting the environment Wednesday]. Regional ecology problems, 2, 12 - 15. [in Russian].

4. Odum, Yu. 1986. Ekologiya [Ecology]. Translation from English. Moscow: Mir, T. 1. [in Russian].

5. Wischmeier, W.H., \& Smith, D.D. (1978). Predicting Rainfall Erosion Losses. Agriculture Handbook, 537.

6. Van der Knijft, J.M., Jones, R.J.A., \& Montanarella, L. (2000). Soil erosion risk assessment in Europe. European Soil Bureau, 34, 8.

7. Kuzmenko, Ya.V., Lisetskiy, F.N., \& Narozhnaya, A.G. (2012). Primenenie basseynovoy kontseptsii prirodopolzovaniya dlya pochvovodookhrannogo obustroystva agrolandshafta [Application of the pool concept nature management for soil conservation arrangement of the agricultural landscape]. Izvestiya Samarsky scientific center of the Russian Academy sciences, 14, 1(9), 2432 - 2435. [in Russian].

8. Smolyaninov, V.M., Degtyarev, S.D., \& Shcherbinina, S.V. (2007). Ekologo-gidrologicheskaya otsenka sostoyaniya rechnykh vodosborov Voronezhskoy oblasti [Ecological and hydrological assessment of the state of the river catchments of the Voronezh region]. Voronezh: Istoki. [in Russian].

9. Belolipskyi, V.O. (2012). Gruntovodookhoronna optymizatsiia ahrolandshaftiv [Groundwater protection optimization of agrolandscapes]. Textbook. Sumy: Universytetska knyha. [in Ukrainian].

10. Directive 20/60/EC of the European Parliament and of the Council of 23 October 20, establishing a framework for Community action in the field of water policy. Official J.I of the European Communities. OIECL 327/1 - 72, Brussels.

11. Naddeo, V., Scannapieco, D., Zarra, T., \& Belgiorno, V. (2013). River water quality assessment: Implementation of non-parametric tests for sampling frequency optimization. Land Use Policy, 30, $197-205$.

12. Belolipskyi, V.O., Baliuk, S.A., Poluliakh, M.M., \& Timchenko, D.O. (V.O. Belolipskoho (Ed.)). (2018). Otsinka intensyvnosti erozino-hidrolohichnykh sytuatsii za baseinovym pryntsypom (metodychni rekomendatsii ta analiz) [Estimation of intensity of erosion-hydrological situations according to the basin principle (methodical recommendations and analysis)]. Kharkiv. [in Ukrainian].

13. Belolipskyi, V.O., Laktionova, T.M., \& Poluliakh, M.M. (2017). Imovirnisna pryroda vmistu humusu y otsinka yoho neodnoridnosti u kartuvanni gruntiv na baseinovii osnovi [Probabilistic nature of humus content and assessment of its heterogeneity in basin-based soil mapping]. Agrochemistry and soil science. Kharkiv: NSC «Sokolovsky Institute of Soil Science and Agrochemistry», 24 - 34. [in Ukrainian].

14. Belolipskyi, V.O., \& Poluliakh, M.M. (2019). Vzaiemodiia faktychnykh i prypustymykh pokaznykiv eroziino-hidrolohichnykh protsesiv na imovirnisnii osnovi [Interaction actual and acceptable indicators erosion-hydrological processes on a probabilistic basis]. Bulletin of Agricultural Science, 8, 52 - 59. [in Ukrainian].

15. Belolipskyi, V.O., \& Poluliakh, M.M. (2020). Zastosuvannia baseinovoi kontseptsii dlia grunto-vodookhoronnoho oblashtuvannia ahrolandshaftiv [Application of the basin concept for soil and water protection arrangement of agrolandscapes]. Bulletin of Agricultural Science, 6 (807) $55-66$. [in Ukrainian].

16. Budnik, S.V. (2007). Optimizatsiya agrolandshaftov [Optimization of agricultural landscapes]. Textbook. Zhitomir: Izd-vo ZhGU im. I. Franko. [in Russian]. 
17. Frans, Dzh., \&Tornli, Dzh. Kh.M. (F.I. Ereshko (Ed.)). (1987). Matematicheskie modeli v selskom khozyaystve [Mathematical models in agriculture]. Translation from English A.S. Kamensky. Moscow: Agropromizdat. [in Russian].

18. Kutsenko, M.V. (2016). Teoretychni osnovy orhanizatsii systemy okhorony gruntiv vid erozii $v$ Ukraini [Theoretical foundations of organizational these systems of soil erosion protection in Ukraine]. Monograph. Kharkiv: Zebra. [in Ukrainian]. 